University of Nebraska - Lincoln DigitalCommons@University of Nebraska - Lincoln

US Fish \& Wildlife Publications

US Fish \& Wildlife Service

1970

\title{
The Effect of Putrefaction of Eggs Upon Residue Analysis of DDT and Metabolites
}

Bernard M. Mulhern

Patuxent Wildlife Research Center

W.L. Reichel

Patuxent Wildlife Research Center

Follow this and additional works at: https://digitalcommons.unl.edu/usfwspubs

Mulhern, Bernard M. and Reichel, W. L., "The Effect of Putrefaction of Eggs Upon Residue Analysis of DDT and Metabolites" (1970). US Fish \& Wildlife Publications. 525.

https://digitalcommons.unl.edu/usfwspubs/525

This Article is brought to you for free and open access by the US Fish \& Wildlife Service at DigitalCommons@University of Nebraska - Lincoln. It has been accepted for inclusion in US Fish \& Wildlife Publications by an authorized administrator of DigitalCommons@University of Nebraska - Lincoln. 


\title{
The Effect of Putrefaction of Eggs Upon Residue Analysis of DDT and Metabolites
}

\author{
by Bernard M. Mulhern and W. L. Reichel \\ Bueau of Sport Fisheries and Wildlife, Patuxent Wildlife Research Center \\ Laurel, Maryland
}

In conjunction with environmental pollution studies, it often is necessary to analyze field-collected eggs that are partially decomposed. The effect of putrefaction upon residue analysis, however, is not known and the experiment reported here was designed to determine if recoveries of DDT, DDE, and DDD differed between fresh and addled eggs and also if putrefaction causes appreciable degradation of DDT.

\section{Procedure}

Thirty-four fresh chicken eggs were randomly selected from "large" size eggs purchased on the open market. The samples, except for controls, were fortified with $p, p^{\prime}-D D T, p, p^{\prime}-D D E$, and $\mathrm{p}, \mathrm{p}^{\prime}-\mathrm{DDD}$ according to the plan outlined in Table 1.

The eggs in group C, D, E, and F were fortified soon after purchase. Fortification was accomplished by syringe injection of the standard solution $(\mu \mathrm{g} / \mu 1)$ through the she11 and we 11 into the egg. The hole produced in the shell was covered with hot paraffin. The eggs in group $C$ and $D$ were frozen immediately. Those in groups $\mathrm{E}$ and $\mathrm{F}$ were allowed to rot in an outdoor open shed, and the rate of decomposition was checked periodically by noting the condition of extra eggs. A period of 4 weeks, during the month of September, was required to obtain satisfactorily "rotten" eggs, which then were frozen.

One additional group of eggs (group A) was frozen fresh without injection and one group (group B) was rotted without injection and then frozen. These samples were fortified when they were opened later at the time of analysis. Two eggs from each of the fresh and rotted group were not fortified and served as background controls.

In addition, five randomly selected fresh eggs from hens fed $25 \mathrm{ppm}$ DDT were frozen fresh and five were allowed to rot with the other sets.

All specimens were stored in a freezer at $-27^{\circ} \mathrm{C}$ for 3 years before they were individually analyzed. 
Each specimen, including shel1, was mixed with anhydrous sodium sulfate, extracted in a soxhlet, and cleaned up by acetonitrile partitioning and florisil column chromatography according to the method of Reichel and Addy (1). The pesticides in the clean extract were analyzed by electron capture gas chromatography on a $3 \%$ OV -17 column and residues were confirmed on $3 \% \mathrm{XE}-60$ column as described by Reiche1 et a1. (2).

\section{Results and Discussion}

The results of the analysis of the fortified eggs are shown in Table 1 as averages of the five individual determinations in each group. The average background level of the control eggs was only 1.6 micrograms of DDE and 1.3 micrograms of DDT, and was not substracted from the values obtained for the experimental eggs.

A statistical F-test analysis of the data showed no significant difference $(P<0.05)$ in the recovery of pesticides from fresh and rotten eggs except that the percentage recovery of DDD from rotted eggs fortified with 200 micrograms was greater than from any other group. The higher values of DDE and DDD in the decomposed eggs (group E and F) suggest that there was some degradation of DDT.

The results of analysis of eggs from hens fed DDT is shown in Table 2. Since these results are reported on a ppm basis, it was necessary to adjust the wet weight of the eggs to compensate for the loss of moisture. The fresh weight was estimated from the egg she11 dimensions (length $\mathrm{x}$ breadth) using the formula suggested by Romanoff (3). A statistical F-test of the data showed no significant difference between the rotten and fresh samples in the levels of DDE or DDT. It is interesting to note that the fresh eggs lost more moisture during freezer storage than did the rotten eggs.

These results show that putrefaction of eggs did not have an appreciable effect on the recovery of DDT and metabolites nor cause conspicuous degradation of DDT.

\section{Acknowledgments}

The authors appreciate and thank our colleagues for assistance in this study; namely, Dr. Lucille Stickel for help in setting up the study and preparation of eggs for analysis, Mr. William Stickel for providing eggs from DDT-dosed hens, and Mr. Robert Heath for assistance in statistical testing of the results. 
Percentage Recovery of Pesticides From Fresh and Rotten Eggs

\begin{tabular}{|c|c|c|c|c|c|c|c|c|c|c|}
\hline \multirow[t]{2}{*}{ Group } & \multirow{2}{*}{$\begin{array}{l}\text { Condition of } \\
\text { Egg Before } \\
\text { Freezing }\end{array}$} & \multirow{2}{*}{$\begin{array}{l}\text { No. } \\
\text { of } \\
\text { Eggs }\end{array}$} & \multirow{2}{*}{$\begin{array}{l}\mu g \text { of Each } \\
\text { Insecticide } \\
\text { DDT, DDE, DDD } \\
\text { Added/Egg }\end{array}$} & \multirow{2}{*}{$\begin{array}{l}\text { Time of } \\
\text { Insecticide } \\
\text { Addition }\end{array}$} & \multicolumn{2}{|c|}{$\mathrm{DDE}$} & \multicolumn{2}{|c|}{$\mathrm{DDD}$} & \multicolumn{2}{|c|}{$\mathrm{DDT}$} \\
\hline & & & & & Mean & $\begin{array}{c}\text { Standard } \\
\text { Error }\end{array}$ & Mean & $\begin{array}{c}\text { Standard } \\
\text { Error }\end{array}$ & Mean & $\begin{array}{l}\text { Standard } \\
\text { Error }\end{array}$ \\
\hline A & Fresh & 5 & 100 & $\begin{array}{l}\text { Before } \\
\text { Extraction }\end{array}$ & 102 & 6.2 & 86 & 1.3 & 84 & .5 .0 \\
\hline B & Rotten & 5 & 100 & $\begin{array}{l}\text { Before } \\
\text { Extraction }\end{array}$ & 93 & 6.2 & 82 & 3.7 & 86 & 3.4 \\
\hline C & Fresh & 5 & 100 & $\begin{array}{l}\text { Before } \\
\text { Freezing }\end{array}$ & 105 & 5.7 & 92 & 6.0 & 88 & 7.3 \\
\hline $\mathrm{E}$ & Rotten & 5 & 100 & $\begin{array}{l}\text { Before } \\
\text { Rotting }\end{array}$ & 113 & 9.8 & 85 & 5.7 & 83 & 1.6 \\
\hline---- & 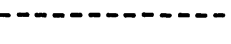 & & $-----n$ & $---1---$ & -- & $--\cdots$ & -- & --- & -- & $---n$ \\
\hline D & Fresh & 5 & 200 & $\begin{array}{l}\text { Before } \\
\text { Freezing }\end{array}$ & 117 & 10.5 & 88 & 3.6 & 82 & 5.2 \\
\hline F & Rotten & 5 & 200 & $\begin{array}{l}\text { Before } \\
\text { Rotting }\end{array}$ & 120 & 3.3 & $100 *$ & 8.2 & 80 & 8.2 \\
\hline
\end{tabular}


TABLE 2

Residues in Eggs From Hens Fed p, p'-DDT

\begin{tabular}{|c|c|c|c|c|c|}
\hline \multirow[t]{2}{*}{ Group } & \multirow{2}{*}{$\begin{array}{c}\text { Wet } \\
\text { Weight }\end{array}$} & \multirow{2}{*}{$\begin{array}{c}\text { Corrected } \\
\text { Wet* } \\
\text { Weight }\end{array}$} & \multirow{2}{*}{$\frac{\text { Residues, }}{\mathrm{p}, \mathrm{p}^{\prime}-\mathrm{DDE}}$} & ppm Corrected & \multirow{2}{*}{$\frac{\text { Wet Weight }}{\mathrm{p}, \mathrm{p}^{\prime}-\mathrm{DDT}}$} \\
\hline & & & & $\mathrm{p}, \mathrm{p}^{\prime}-\mathrm{DDD}$ & \\
\hline \multirow[t]{6}{*}{ Fresh } & 29.40 & 52.03 & 5.21 & - & 11.41 \\
\hline & 38.19 & 52.20 & 2.62 & $<0.05$ & 9.95 \\
\hline & 36.18 & 53.06 & 6.00 & $<0.05$ & 10.98 \\
\hline & 39.82 & 53.06 & 3.15 & $<0.05$ & 6.79 \\
\hline & 38.41 & 54.72 & 5.27 & $<0.05$ & 9.35 \\
\hline & & Mean & 4.45 & & 9.70 \\
\hline \multirow[t]{6}{*}{ Rotten } & 46.62 & 51.34 & 2.73 & $<0.05$ & 6.31 \\
\hline & 48.42 & 52.92 & 2.61 & $<0.05$ & 6.81 \\
\hline & 47.80 & 50.49 & 5.33 & $<0.05$ & 10.04 \\
\hline & 50.96 & 53.82 & 6.24 & $<0.05$ & 11.77 \\
\hline & 43.67 & 48.11 & 2.78 & $<0.05$ & 6.89 \\
\hline & & Mean & 3.94 & & 8.36 \\
\hline
\end{tabular}

*Corrected for loss of weight as described in text

\section{References}

1. W. L. Reichel and C. E. Addy, Bull. Environ. Contam. and Toxicol., $\underline{3}, 174$ (1968).

2. W. L. Reichel, T. G. Lamont, E. Cromartie, and L. N. Locke, ibid, 4, 24 (1969).

3. A. L. Romanoff and A. J. Romanoff, The Avian Egg, p. 108 (1963), John Wiley and Sons, New York. 